\title{
Een vergelijking van De boeren van Władysław Reymont met De vlaschaard van Stijn Streuvels en de receptie van De boeren in Nederland
}

\begin{abstract}
Władysław Stanisław Reymont and Stijn Streuvels were at the end of the nineteenth and early twentieth centuries among the internationally best known writers of their respective literatures. In 1924 Reymont received the Nobel Prize for Literature, Streuvels has been 13 times nominated for this prize (Dijk, Vaartjes 1993: 10). Both authors are typical representatives of the regional literature but their novels have, however, themes that are reaching beyond the strict focus of this genre. The discussed novels Chtopi (The Peasants) and De vlaschaard (The flaxfield) have been translated into many languages. This article focuses on the reception of Chtopi in the Low Countries and compares the themes of both novels. Despite the different contexts of both novels, there are many similarities between these books, e.g. homesickness, nostalgia for the times which passed away, longing for the old villages. The construction of the literary characters is also similar: the protagonists are outlined simply and straightforwardly.
\end{abstract}

Keywords: Stijn Streuvels, Władysław Reymont, translation, reception, De boeren, De vlaschaard

\section{Voorwoord}

Het uitgangspunt van dit artikel is een vergelijking van twee romans over het boerenleven, de Poolse roman Chtopi [De boeren] van Władysław Reymont, en de Vlaamse roman De vlaschaard van Stijn Streuvels. Beide boeken werden begin twintigste eeuw gepubliceerd.

Eind twintigste eeuw ontstond er in de vergelijkende literatuurwetenschap een nieuwe discipline, de comparatieve poëtica. Deze is voor Polen gebaseerd op de comparatistische theorie van de Russische onderzoeker Aleksander Wiesiołowski, alsmede op studie van folklore en nationale psychologie. De centrale term van deze comparatisten is het literaire genre. De Franse wetenschapper Daniel-Henri 
Pageaux (*1939) stelt dat de beelden van dit genre van nut zijn bij bestudering van invloed, imitatie en receptie van prototypische teksten.

In de laatste jaren is de interculturele comparatistiek zeer populair. Deze onderzoekt literaire verschijnselen in culturen die geografisch ver van elkaar liggen en tussen welke geen invloed of directe uitwisseling is geweest. In deze discipline speelde Earl Roy Miner (1927-2004) een belangrijke rol. Hij heeft teksten uit verschillende nationale literaturen vergeleken door formele en structurele kenmerken te analyseren. Daarbij legde hij tevens nadruk op het proces van de literaire communicatie (zoals de afzender, tekst, ontvanger) en kwesties met betrekking tot methoden van de maatschappelijke productie van de literatuur en culturele omstandigheden van het functioneren van de literatuur. In de jaren tachtig van de twintigste eeuw richtte de comparatistiek zich op de culturele theorie. Onderzoekers contextualiseerden de literatuur in het uitgebreide discours op cultuur, ideologie, ras, etniciteit en geslacht. In het kader hiervan wordt ook de voorheen gemarginaliseerde regionale literatuur opnieuw gelezen.

In deze bijdrage wil ik twee belangrijke literaire werken van Reymont en Streuvels summier vergelijken in het kader van de genre-aannames. Ik richt mij daarbij op de structuur van beide boeken.

\section{Het verschijnsel streekliteratuur}

Chłopi, de belangrijkste roman van Reymont, omschrijft het boerenleven in het dorpje Lipce. Hoewel de term 'streekroman' in de Poolse literatuur niet bestaat, zijn er in het Pools wel met het Nederlandse begrip 'streekroman' verwante termen als 'milieuroman' of 'regionale roman'. Chtopi beantwoordt aan de karakteristieken ervan, aangezien de roman een doorsnede van de boerenwereld creëert. De vlaschaard van Stijn Streuvels wordt in het algemeen een streekroman genoemd. Op het gebied van de Vlaamse literatuur zijn er diverse termen die de streekliteratuur omschrijven. A. Feitsma (1976: 6) definieert bijvoorbeeld de term als volgt: "Onder streekliteratuur of Heimatliteratuur zouden we kunnen verstaan literatuur die in de eigen streek of Heimat (of in andermans eigen streek) speelt en/of daarop gericht is".

Door vergelijking van beide werken van Reymont en Streuvels kunnen we ontdekken hoe dit genre de enorme culturele diversiteit en rijkdom van tradities in de sociale relaties op het platteland toont. Daarbij is vooral de presentatie van de personages interessant. Dankzij de psychologische portretten van de hoofdpersonen zijn streekromans boeiend en indrukwekkend.

André Demedts (1982) onderzoekt in zijn artikel Streekliteratuur de opbloei van dit genre begin twintigste eeuw. Hij zet de Vlaamse ontwikkeling in de context van de wereldliteratuur. In de nieuwste editie van het Algemeen Letterkundig Lexicon (2012: 935) wordt de streekliteratuur als volgt gedefinieerd: 
Literatuur die wordt gekenmerkt door de beschrijving van een bepaalde landelijke streek en de bewoners daarvan [...]. De nadruk ligt daarbij op het eigene van de beschreven regio, waarbij de sociale verhoudingen binnen een kleine gemeenschap de hoofdrol spelen, maar ook dialect en folklore die de eigen aard van de streek tot uitdrukking brengen, al is het maar vanwege de couleur locale. Ook de wisselwerking tussen mens en omgeving krijgt in deze regionale literatuur een sterk accent.

Hoewel de geschiedenis, taal en cultuur in Polen en Vlaanderen compleet anders zijn, blijken beide romans De Vlaschaard en De boeren veel gemeenschappelijke elementen te hebben. Ze ontstonden in dezelfde periode (De Vlaschaard in 1907 en De boeren in de jaren 1904-1909). Wederzijdse beïnvloeding van beide teksten is echter vanwege o.a. de taalbarrière uitgesloten. Het is interessant om beide romans te vergelijken en zo het genre te analyseren vanuit diverse perspectieven en contexten (historisch, cultureel, sociaal of biografisch). De hoofdprincipes van het genre werden bovendien vrijwel gelijkvormig gerealiseerd, hoewel de auteurs elkaars teksten niet kenden. Deze principes zijn o.a. beschrijving van een bepaalde landelijke streek en de bewoners daarvan; beschrijving van de sociale verhoudingen en folklore; het gebruik van dialect; beschrijving van de band tussen mens en natuur (Algemeen Letterkundig Lexicon 2012: 935).

Het uitgangspunt van beide romans is vergelijkbaar. Reymont schreef in het nog zeer agrarische Polen. Streuvels schreef ook in het eveneens nog rurale België, al was dat land al sterker geïndustrialiseerd dan Polen. Toen Polen in 1918 zijn onafhankelijkheid terugkreeg, woonde nog meer dan driekwart van de totale bevolking op het platteland. De economische situatie van landbouwers in beide landen was destijds sterk vergelijkbaar - plattelanders leden vaak armoede en hun kinderen hadden nauwelijks toegang tot onderwijs. Boeren werden door de machthebbers stevig onder druk gezet. Poolse en Vlaamse auteurs die over dit landelijke onderwerp schreven, beklemtonen in mijn optiek duidelijk dat de onderontwikkeling van de boer niet de schuld is van de dorpsbewoners zelf, maar van de rijke leiders die invloed hadden op het economische bestuur van de staat.

De romans van Reymont en Streuvels wil ik volgens het volgende schema analyseren ${ }^{1}$ :

1. Hoofdthema

2. Vertelsituatie en de taal

3. Belangrijkste motieven

${ }^{1}$ De analyse is vooral gebaseerd op de volgende publicaties: Bemong 2000, De Geest e.a. 2005, Gazda \& Tynecka-Makowiecka 2006. De auteurs van deze publicatie verspreiden hun analyse en onderzoeken de romans ook in het kader van: plaats en tijd, de band tussen mensen en ruimte, literaire stroming, volksgewoontes, het conflict tussen dorp (iets inheems) en stad (iets uitheems), het verband tussen mens en natuur, de boodschap van het boek. In dit artikel beperk ik mijn onderzoek tot de elementen hoofdthema, vertelsituatie, taal en belangrijkste motieven. 


\subsection{Hoofdthema}

Zowel in De vlaschaard als in Chtopi is het bestaan van de boer één van de belangrijkste thema's. In beide romans zijn er gemeenschappelijke motieven te vinden, al werden deze werken in heel verschillende delen van Europa gecreëerd en kwamen ze uit verschillende literaire en nationale tradities voort.

De handeling draait bij Streuvels rond het confict tussen boer Vermeulen en zijn zoon. Bij Reymont krijgt in Chłopi de strijd tussen boer Maciej Boryna en zijn zoon Antek eveneens de meeste aandacht. Beide werken tonen een veelzijdig, bijna archetypisch conflict tussen twee generaties. De verwijzingen uit de titels (vlaschaard en boeren) worden gebruikt als signaal om het hoofdthema van de roman te laten zien. Streuvels was de eerste in de Vlaamse literatuur die deze problematiek heeft geïmplementeerd. Mogelijk liet hij zich inspireren door Ivan Toergenjevs roman Oтизы и дети (Vaders en zonen). Hedwig Speliers schrijft dat de intergenerationele onenigheid in het boek van Streuvels een universele boodschap heeft, omdat ze niet beperkt is in de tijd (Speliers 1994: 305).

De strijd tussen vader en zoon is in de roman van Streuvels sterker aangezet dan in het werk van Reymont. Het conflict van Louis en Vermeulen is een typisch generatieconflict, ongeacht cultuur of taal, maar krijgt zijn concrete vorm als gevolg van de opstelling van vader Vermeulen. Deze kan zijn leeftijd niet accepteren, omdat zijn heerschappij op de boerderij binnenkort zal eindigen. Hij wil zijn vermogen en rijkdom niet overdragen aan zijn zoon. De natuurlijke orde der dingen komt niet overeen met zijn ideeën, ondanks het feit dat de overdracht van bezit een gewone zaak was bij dorpsgezinnen. Het lijkt wel of Vermeulen zelfs niet blij is dat hij een zoon heeft, dus iemand die zijn heerschappij over de grond kan overnemen. Toen Louis nog klein was, zag Vermeulen geen gevaar voor zijn macht. De situatie veranderde tijdens de zaaihede van het vlas. Louis wil modernere landbouwmethodes toepassen en verzet zich zo tegen de ideeën van zijn vader. Louis heeft toen voor het eerst woede in de ogen van zijn vader opgemerkt. De vlaschaard is het drama van verkeerd opgevat vaderschap, het drama van het gevreesde, het onomkoombare en toch zo lang mogelijk uitgestelde doorgeven van de macht.

In het werk van Reymont kan men een identieke situatie ontdekken. Ook daar heeft vader Maciej Boryna moeite om te accepteren dat zijn zoon Antek het bestuur van de boerderij zal overnemen. Zijn tijd is voorbij en dat is de bron van zijn frustratie. Na de dood van zijn vrouw trouwde Boryna met het mooiste meisje van het dorpje, een jonge meid, om zijn aantrekkelijkheid en kracht te bewijzen. Hij toonde zo zijn tweede jeugd. Dit conflict tussen vader en zoon is zeer geaccentueerd, maar tegelijkertijd vergezeld van andere motieven. Reymont besteedt veel meer aandacht dan Streuvels aan de schildering van het leven van andere gezinnen en arbeiders. Zoals de titel al suggereert, beschrijft de Poolse Nobelprijswinnaar 
de dorpsgemeenschap in het algemeen. Hij beperkt zich niet alleen tot het dorp Lipce waar de actie zich afspeelt. Reymonts thema is wat destijds Polens grootste sociale klasse was: het bestaan, de cultuur, de overtuigingen van plattelandsmensen, hun voor- en nadelen en de algemene conditie van deze bevolking (Skoczek 2005: 245).

\subsection{Vertelsituatie en de taal}

Zowel in De vlaschaard als in Chtopi is er een alwetende verteller (volgens de typologie van Stanzel, Sławiński 2002: 331) of hij-vertelling (volgens de typologie van Genette 1972) die het verhaal in de derde persoon enkelvoud vertelt. Op die manier krijgt de lezer een zeer exact beeld van de wereld van toen. Van tijd tot tijd stapt de verteller over op persoonlijke focalisatie, vooral als hij de centrale personages Vermeulen, Louis of Schellebelle en Barbele uitbeeldt. De verteller is betrokken bij het verhaal, maar praat er niet over in de eerste persoon enkelvoud. Hij spreekt dus alsof hij een personage van het boek was, bijvoorbeeld:

Dan voelde Louis een geweld, eene strooming die naar buiten wilde - hij onderdrukte en toomde zijn gemoed maar de wrok vunsde voort, groeide tot een aanhoudenden afkeer tegen de grove zware gestalte van zijn vader (Streuvels 1907: 27).

Vermeulen wist zich daar alleen en gerust. [...]. Hij verlangde nu niets anders dan gerust te mogen zitten hier bij ,t bed en te denken want de gedachten die hem nooit bezocht hadden, bestormden hem nu en zoolang hij alleen was kon hij zich overgeven aan zichzelf en in alle oprechtheid de zaken inzien gelijk ze waren (Streuvels 1907: 315).

Het beeld dat de lezer krijgt van de natuur, bijvoorbeeld via het bewustzijn van Louis, wordt wel aangevuld door een auctoriële instantie. De verteller stelt de natuur en de personages met auctoriaal gezag en privileges (Janssens 1992: 7).

De vertellerinstantie in Chłopi is polyfonisch. Kazimierz Wyka stelt: “(...) In De boeren verschijnen er drie aparte vertellers: ten eerste een moderne verteller, ten tweede een regionale babbelaar en ten derde een realistische toeschouwer" (Wyka 1968: 126). ${ }^{2}$

De taal van de romans van Reymont en Streuvels bevat elementen van het dialect. Streuvels heeft voor zijn personages een collage van diverse Vlaamse dialecten gemaakt. Reymont creëerde ook een collage van verschillende dialecten die destijds in Polen gesproken werden. Bovendien heeft de auteur van Chtopi zijn tekst verrijkt met allerlei spreekwoorden en gezegden. Świrko stelt dat ze voornamelijk uit de volkstraditie komen en mondeling van generatie op generatie doorgegeven werden (Świrko 1961).

De vlaschaard is geschreven in een bondige stijl. De beschrijvingen van de natuur zijn zeer schilderachtig. In het werk van Streuvels is het naturalisme de do-

${ }^{2}$ „(...) w Chłopach pojawiają się trzy oddzielne struktury narracyjne, trzy wcielenia narratora: młodopolski stylizator, wsiowy gaduła i realistyczny obserwator” (Mijn vertaling, JW). 
minante conventie (Speliers 1994: 307). In het werk van Reymont is het realisme de dominante conventie. Het impressionisme is eveneens duidelijk zichtbaar zowel in De vlaschaard, als in De boeren, vooral in de beschrijvingen van de natuur. De natuur in De vlaschaard werd vaak door de auteur gepersonaliseerd. Het wordt beschouwd als een moederland dat onder andere gewassen van de aarde oplevert: "omdat de lucht, het land milde en gereed waren om het zaad groeiveerdig te ontvangen" (Streuvels 1907: 47).

\subsection{Belangrijkste motieven}

Motieven die in streekromans verschijnen betreffen vooral familie, boerderij en natuur. Deze worden tegenwoordig vanuit diverse gezichtspunten gelezen en verbonden met identiteit, individualiteit en dergelijke. Deze richting in het onderzoek komt voort uit de overtuiging dat literatuur de nationale landschappen creëert (Ihnatowicz 1997). Laten we hier de belangrijkste motieven even bekijken.

De natuur is erg belangrijk in de streekromans. Hiermee hangt de kringloop van de seizoenen samen. Tom Sintobin stelt dat in Streuvels' visie mens en natuur nauw verbonden zijn. Het leven van de mens wordt weerspiegeld in het leven van de natuur:

In het geval van De vlaschaard zou men kunnen argumenteren dat het verhaal van de natuur onmiddellijk al begint en eenomkadering vormt voor het verhaal van de personages (Sintobin 2002: 48).

De mens moet de natuurlijke orde respecteren. De eerste fout van Vermeulen is dat hij, alleen omwille van de tegenspraak, de natuur niet volgt (zo zet hij de oogst te laat in, zodat het onweer de werkers overvalt). Vermeulen kan dit onweer niet accepteren.

De Natuur (geschreven met een hoofdletter) is almachtig en onbeheerst. Dergelijke verwijzingen naar de natuur verschenen eerder al in andere werken van de wereldliteratuur, bijvoorbeeld bij Knut Hamsen, Charles-Ferdinand Ramuz of John Steinbeck. Het verband tussen de mens en de allesoverheersende natuur is ook in Chłopi zeer opmerkelijk. In het werk van Reymont is de natuur onweerstaanbaar, ze is de enige drijfkracht. Mensen volgen noodgedwongen de grillen van weer en seizoen.

Het menselijke bestaan is in deze Poolse roman overigens niet alléén afhankelijk van de natuur maar ook van de regels van de dorpsmaatschappij. Zo wordt Jagna, die de sociale gedragsregels niet respecteert, verbannen. In het oeuvre van Reymont wordt de lezer bovendien geconfronteerd met een mystiek begrip van de aarde. De gevoelens die de personages hebben voor het land zijn doordrongen van de geest van het christendom. Bovendien is grondbezit onlosmakelijk verbonden met het werk en de roman zelf is een soort loflied op het voortdurende en vruchtbare werk op het land. Reymonts beschrijvingen van de natuur presenteren de re- 
latie tussen mens en natuur, maar verwijzen vaak ook naar de psychische toestand van de personages. Zo gaat de vrouw van Antek Boryna, Hanka, opeens tijdens de winter naar het bos. De nauwkeurige beschrijving van het bos is triest, koud, melancholisch, net als de stemming van Hanka, die toen veel problemen had.

Dit verschijnsel is ook zichtbaar in De vlaschaard. Een beschrijving van een sterke, donkere winter is slechts een voorwendsel om de emoties van de figuren te tonen. In De vlaschaard is de relatie tussen mens en natuur duidelijk aangegeven door de allegorie van de oude en de jonge boom als beeld van vader (Vermeulen) en zoon (Louis). Dit feit is een centraal probleem in het werk van Streuvels. De hoofdpersoon kan niet accepteren dat zijn zoon binnenkort klaar zal zijn om te regeren op de boerderij. De houding van Vermeulen was de aanleiding tot een groot conflict van twee generaties met een tragisch einde. Dit conflict is ingebed in de vier seizoenen van het jaar, het begint in de lente en culmineert in het najaar.

Ook Reymont benadrukt de waarde van de vier seizoenen alleen al door aan de hoofstukken van zijn boek de namen van de seizoenen (vanaf de herfst) mee te geven. Het seizoen lijkt de gang van zaken en menselijk gedrag te bepalen. In de orde van de natuur heeft Reymont ook de 'heilige tijd' ingevoerd. De gewone kalender was namelijk sterk verbonden met de liturgische tijd. De tijd van de natuur en de religieuze tijd tonen in deze roman de metafysische zin van het menselijke leven. Ook andere beelden die in het boek voorkomen hebben vaak hun bron in de mythe. De scène van het laatste zaaien van Boryna is een verwijzing naar het oorspronkelijke moment van de schepping van de natuur en de mens. Ook het fragment over het zaaien van De vlaschaard is hiermee vergelijkbaar. De man-zaaier is de gever van het leven. In de roman van Streuvels is de afwisseling van de generaties zichtbaar. In het oeuvre van Reymont zaait de vader, in De vlaschaard daarentegen de zoon.

De beschrijvingen van de natuur en het landschap zijn in beide romans zeer gelijkaardig in het perspectief van de taal. Reymonts uitbeelding van de natuur is zeer uitgebreid. Het vertraagt zelfs de ontwikkeling van de handeling. De omschrijvingen zijn vol kleuren, vooral groen en licht, als de verteller over de zomer vertelt, en vol duisternis en monotonie, als de verteller over de winter spreekt. Gedetailleerde beschrijvingen van kleuren of het spel van het licht in het landschap tonen hun impressionistisch karakter. Natuurverschijnselen, zoals bijvoorbeeld een beschrijving van de storm, worden nauwkeurig gepresenteerd, in overeenstemming met het naturalisme. Ook het beeld van het landschap is in Reymonts roman naturalistisch. De schrijver beeldt de akker, omgeving, planten en dieren zorgvuldig uit. Bovendien zijn deze beschrijvingen heel schilderachtig en kleurrijk.

Religie en folklore zijn voor de boer een gemeenschappelijk concept van de wereldorde. De werkelijkheid van het boerenleven wordt gezien als een ordentlijk en harmonieus geheel, gebaseerd op traditie en geloof. Volksgewoontes en religeuze gebruiken die met elkaar vervlochten zijn, worden door Streuvels en Rey- 
mont op kleurrijke wijze getoond. Beiden laten zien dat het geloof een integraal onderdeel van het boerenleven is en niet alleen met de feestdagen verbonden is. Ook in het dagelijks leven waren religieuze riten diep geworteld in de landelijke samenleving. Beiden benadrukken dat de plattelanders, hoewel ze trouw zijn aan de christelijke traditie, zich lang niet altijd moreel gedragen. Marcel Janssens beschrijft dit zo:

De religieuze belevingen met al die praktijken en devoties die daarrond hangen in Streuvelsland, is een min of meer gekerstende en met christelijk bijgeloof vermengde natuurreligie op basis van angst [...] angst voor de Opperste Baas die de grote elementen gebiedt, de Opperheer, de machtige regelaar van de zon (Janssens 1972: 126).

Zowel in De vlaschaard als in De boeren wordt het aspect van de religieuze gemeenschap getoond. Als bewijs daarvan kan worden verwezen naar het moment van het zaaien. Louis maakt vóór het zaaien tweemaal het kruisteken net als Boryna: "Dan deed Louis als een priester die de mis gaat lezen: hij stroopte zijn lang witlinnen zaaikleed aan en sloeg een kruis over de borst" (Streuvels 1907: 43). Op deze manier wordt de grond gesacraliseerd. Adamowski (1995: 25) stelt dat het kruis in de boerentraditie in verschillende gewoonten en rituelen verschijnt. Het was een veel voorkomende gewoonte dat de werkzaamheden met het teken van het kruis begonnen. De boeren hechtten veel belang aan de eerste arbeid op het veld omdat die de nieuwe vegetatiecyclus opent. Men geloofde dat dit werk invloed had op de ontwikkeling van planten en toekomstige vruchtbaarheid, voorspoed en geluk voorspelde. De eerste dag van het werk in het voorjaar was daarom omringd door vele praktijken die in de negentiende eeuw niet meer met heidense praktijken verbonden waren, maar vooral een christelijk karakter hadden (Niewadomski 1995: 82). Een ander christelijk gebruik is de gewoonte om Palmzondag te vieren. Streuvels toont hoe de mensen op het platteland naar de mis gaan, naar de kerk. De vreugdevolle mensen dragen palmtakken (eigenlijk buxustakjes) en ze geloven dat deze gewijde palmen hun huis tegen ziektes en gevaar zullen beschermen. $\mathrm{Na}$ de mis gingen de boeren naar het veld met de palmtakjes.

Een zeer belangrijke religieuze ceremonie voor de inwoners van het dorp was ook de processie met het kruis die plaatsvond tijdens de zogenaamde Kruisdagen, drie dagen voor het feest van Hemelvaart. Iedere voorbijganger die de stoet op zijn weg ontmoette hield een moment stil voor het Heilige Kruis: "Waar er landlieden te werken staan als de processie voorbij komt, houden zij stil, doen de muts af en staan ingetogen zoolang tot de stoet voorbij is" (Streuvels 1907: 78-79).

De Kruisdagen werden ook gevierd in het dorp van Chtopi als een tijd van gebed voor een goede oogst. De boeren namen deel aan de processie die naar kapellen en de plaatselijke kerken ging (Encyklopedia 1985: 1362-1363). De gezinnen uit Lipce (het dorp uit Reymonts roman) namen elk jaar deel aan de kruisprocessie (in de roman genoemd "lopen naar de figuren") die volgens Gloger werd losgemaakt van het kerkelijk jaar en omgevormd tot een heilige rite. Men geloofde dat 
de deelname aan de processie voor een goede oogst op de akkers en welvaart in de boerderijen zal zorgen (Gloger 1958: 210).

De boeren zijn zeer gehecht aan de religie van hun voorouders. Zij is de basis van hun bestaan. Zij proberen alle belangrijke gebeurtenissen in hun leven te beginnen met God, en niet alleen hun bruiloften en doopfeesten. Reymont presenteert tevens andere traditionele religieuze rituelen als Kerstgewoontes, Paasrituelen, de wijding van velden en gewassen. Dit zijn momenten vol emoties. De inwoners van Lipce zijn zeer actief in het behoud en zelfs uitbreiding van de volkscultuur. Reymont presenteert elke rite die was geassocieerd met de liturgische kalender. In Chłopi wordt de klederdracht zeer overzichtelijk gepresenteerd. Ook deze is een onderdeel van de streektraditie. Volgens de verteller dragen de boeren prachtige klederdracht uit streek Łowieckie.

Streuvels toont in De vlaschaard minder vaak boerengewoonten dan Reymont dit doet in zijn oeuvre, maar als hij het doet, wel met een grotere nauwkeurigheid en precisie. Een voorbeeld hiervan is de beschrijving van de vlasoogst van Vermeulens buurman Sorbie. Reymont geeft eerder de voorkeur aan een thematisch verbonden presentatie van gebruiken bijvoorbeeld in verband met feestdagen, met oogsten of het werk thuis tijdens de winter. Daarom heeft hij veel tradities en rituelen beschreven die het hele jaar door in Lipce plaatsvonden.

Familie is zeer waardevol. Ondanks de hedendaagse crisis van de familiecrisis in de Europese cultuur is het gezin nog steeds een plaats van zelfverwerkelijking, de plaats die een koesterende, goede en warme omgeving biedt zowel voor de kinderen als voor de echtgenoten (Brzóstowicz 1988: 7). Traditionele streekromans als De vlaschaard en Chtopi tonen het gezin als de eeuwige basisstructuur van alle relaties. Vaak wordt de familie wordt voorgesteld als een grote, multi-generatiegemeenschap, gebaseerd op complexe relaties van verwantschap. Zoals eerder vermeld werd, wordt in De vlaschaard het conflict tussen de twee generaties van vader en zoon beklemtoond. Het conflict is geworteld in het egoïsme van Vermeulen, in zijn verlangen om te regeren over de grond tot het einde van zijn leven. Door zulk gedrag vernietigt vader de relatie met zijn zoon.

Het misverstand tussen vader en zoon wordt ook door Reymont gepresenteerd. Maciej wil het land niet aan Antek overdragen om zijn positie in het gezin en in de boerengemeenschap niet te verliezen. Daarnaast wordt het conflict verergerd door Anteks affaire met zijn stiefmoeder Jagna. Reymont en Streuvels tonen het generatieconflict op een vergelijkbare wijze. De bron van het conflict is dezelfde: beide vaders zijn dominant, gebiedend, en niet in staat om hun macht aan de opvolger te overhandigen. Ze gaan dus tegen de natuurlijke orde der dingen in.

In De vlaschaard is het vader-zoon conflict het ergste. Vermeulen verwondt zijn zoon ernstig. Dit tragische feit brengt in de onverbiddelijke vader volgens Marcel Janssens een soort catharsis teweeg (Janssens 2007: 111). Bovendien komt bij Streuvels het woord "noodlot" geregeld voor. Hiermee sluit hij aan bij de in het Nederlandse naturalisme kenmerkende noodlotsidee (Debbaut: 183). 
Vermeulen is een slachtoffer van zijn eigen hoogmoed. Door de vernieuwingen van zijn zoon niet te accepteren wil hij tonen beter te zijn. Hij plant de oogst te laat en slaat bovendien in blinde drift zijn zoon, waarmee hij tevens de toekomst van zijn eigen bedrijf vernietigt. Hij is diep geworteld in de rituelen en eigen overtuigingen. Door uitgebreide schildering van zulke rituelen demonstreert Streuvels achtergeblevenheid van het platteland. Het platteland is niet bereid om de kern van menselijke karakters en hun goede bedoelingen als het meest waardevolle te accepteren. De natuurlijke (noodlottige) wetmatigheden krijgen de overhand, waardoor degenen die tegen de wetmatigheid van de progressie ingaan, worden gestraft.

$\mathrm{Na}$ de schandelijke daad is Vermeulen zich niet alleen van zijn fouten in de relatie tot zijn zoon bewust, maar bezint zich ook op zijn relatie jegens Barbele: hij begint zijn vrouw te beschouwen als een wijze en liefdevolle vrouw. Barbele zegt niets, hoewel zij weet wat haar man hun eigen zoon heeft gedaan, blijft stil, ze wil geen wraak. Vermeulen bewondert haar erom. In de kamer van Louis laat de vrouw boer Vermeulen alleen zijn met de gewonde zoon en stilletjes gaat ze naar buiten. Het zwijgen van de lijdende moeder is naar mijn mening niet (zoals Janssens 1972: 119 schrijft) een uitdrukking van ruwheid en afkeer, maar eerder een uiting van respect voor het lijden van haar echtgenoot die waarschijnlijk alleen wil blijven met zijn zoon. In Chtopi is de onenigheid tussen vader en zoon niet zo verwoestend als in de roman van Streuvels. Er is zelfs sprake van intergenerationele verzoening. Aan het einde van het boek worden alle draden betreffende familierelaties optimistisch aanelkaar geknoopt.

In het oeuvre van Streuvels en Reymont speelt de moeder (en vrouw) steeds een bemiddelende rol. Barbele, de vrouw van Vermeulen probeert de emoties van haar man af te koelen. Ze accepteert zijn daad tegen de zoon niet, maar ze steunt hem in deze moeilijke periode wanneer Vermeulen naast het bed van Louis waakt. In Reymonts roman speelt Hanka, de vrouw van Antek en de moeder van zijn kinderen, de rol van 'de moeder van familie'. Hanka respecteert haar schoonvader die rijk is en een goede positie in het dorp heeft. Zij houdt van Antek en vergeeft hem dat hij vreemd is gegaan. $\mathrm{Zij}$ doet een extreem grote inspanning, offert haar gezondheid en tijd, verwerpt haar gevoelens van rouw en verdriet, wordt een sterke vrouw om haar man en het hele gezin te redden (Rurawski 1988).

De familie in De vlaschaard was niet gelukkig. De relatie tussen de leden van het gezin waren zeer koel. Barbele probeerde ten koste van alles de warmte in het huis op te wekken, maar de houding van Vermeulen was niet gunstig voor het opbouwen van positieve relaties. In het gezin van Boryna zijn de verhoudingen tussen Maciej, Antek, Jagna en Hanka zeer complex en ingewikkeld. De liefde van Boryna tot zijn vrouw stopte, toen hij ontdekte dat Antek en Jagda een affaire hebben. Boryna begon zijn zoon te haten. Hij voelde zich beledigd in zijn ambities als man, echtgenoot en vader. 
De liefde van Boryna tot zijn kinderen wordt in de eerste plaats uitgedrukt door de zorg voor hen. Maar hij was niet gevoelig jegens hen. Hij vereist van zijn kinderen alleen werk en absolute gehoorzaamheid. Maciej wenste Antek geen gastheer op de boerderij te maken. Hij wilde zijn eigen positie in het gezin en de dorpsmaatschappij niet verliezen. Ondanks het feit dat Maciej een moeilijke relatie met zijn zoon had, hield hij van Antek. Het bewijs daarvan kan de vreugde van Boryna zijn, als zijn zoon Antek hem verdedigde had tijdens het gevecht om het bos.

Antek is in strijd met iedereen, met zijn vader wegens de affaire met Jagna en vanwege het probleem dat de overname van de boerderij betreft. Zijn passie voor Jagna, de overtreding van normen en waarden, plaatst Antek in een conflictsituatie met het hele dorp. Bovendien is Antek afhankelijk van zijn vader. Hij is een volwassen man met vrouw en kinderen en toch moet hij zijn vader om elke cent vragen. Boryna benadrukt vaak tegen Antek: "Brood spreid je uit, zie ik ... mijn brood" (Reymont 2000: 36). ${ }^{3}$

Reymont presenteert in Chtopi een volledig beeld van de families in drie generaties: vaders, kinderen en kleinkinderen. Tot de oudste generatie behoren: Maciej Boryna, Płoszka, Sokora, Artemisia, de burgemeester, dus de mensen die zich de tijd van de lijfeigenschap nog herinneren. Maar één ding is zeer belangrijk en verbindt alle generaties: de grond. De ouders proberen om zoveel mogelijk moment van de overdracht van hun grond aan de kinderen uit te stellen. Als de ouders de boerderij overdragen, willen hun kinderen hen namelijk niet langer in hun eigen huis houden. De ouders zijn bang voor deze vreemde situatie. De jonge generatie is progressiever en streeft naar veranderingen. Veel jonge boeren kunnen lezen en schrijven. Sommigen zijn klaar om naar het buitenland of naar de stad te gaan voor het werk, zoals bijvoorbeeld Antek. Vaak accepteren ze het standpunt van vaders en grootvaders niet.

Hier moet nog worden opgemerkt dat Reymont in zijn roman niet slechts één familie (de Boryna's), maar ook andere families als de Paczesiows en Bylicows heeft voorgesteld. De meest uitgebreid zijn de avonturen van het gezin van protagonist Maciej Boryna beschreven. Zo kon Reymont ook het leven van anderen tonen en een panorama van het leven van de plattelandsbewoners vormen. Dit maakt het oeuvre van Reymont uniek in vergelijking met andere regionale romans.

\section{Receptie}

Voor Chłopi, de bekendste roman van Władysław Stanisław Reymont (18671925), uit 1904-1909, kreeg de schrijver in 1924 de Nobelprijs voor literatuur. De

3 „Chleb cię to rozpiera, widzę... mój chleb”. 
roman is in vele Europese talen vertaald. De eerste vertaling van dit werk ontstond al in het interbellum: in 1920-1921 werd de roman door Karel V. Rypáčka in het Tsjechisch vertaald. De andere zijn pas van na de Novelrpijs: in 1925 kwam de Engelse vertaling door Michael A. Dziewicki uit, in 1925-1926 vertaalde Frank L. Schoell de roman in het Frans. Schoell is ook de auteur van de Franstalige studie Les Paysans de Ladislas Reymont over Chlopi (Schoell 1925).

De roman van Władysław Stanisław Reymont is zowel in Nederland als in België in het Nederlands vertaald en gepubliceerd onder de titel De boeren. De eerste editie kwam in Nederland in 1926 uit bij uitgeverij Scheltens \& Giltay in Amsterdam in een vertaling door Gustaaf van Eycken. De tweede uitgave uit 1930 in een vertaling door Abraham E. Boutelje en M. L. Auerbach verscheen ook bij dezelfde uitgeverij (Kocówna 1975: 397). De laatste vertaling door Hans C.M. Fens werd in 1960 uitgegeven bij De Toorts in Haarlem in de reeks Pantheon der winnaars van de Nobelprijs voor literatuur. In België kwam het werk van Reymont eveneens in de vertaling door Hans C.M. Fens in 1960/61 uit bij uitgeverij Heideland in Hasselt (Kocówna 1975: 392).

In 1916 werd de roman door Jean-Paul Kaczkowski onder het pseudoniem Jean d'Ardeschah in het Duits vertaald. Kaczkowski stelde het werk van Reymont zeer op prijs. In 1924 werd de bijdrage gepubliceerd in Dietsche Warande en Belfort waarin Kaczkowski (1924: 950) schreef:

$\mathrm{Na}$ Henryk Sienkiewicz, den auteur van de beroemde Poolsche trilogie uit Polen's strijd met Kozakken en Tartaren en van den roman 'Quo Vadis', is Wladyslaw Reymont beroemde schrijver van het boerenleven in Polen. Zelf uit den boerenstand - in zijn jeugd heeft hij de ganzen zijns vaders gehoed - is Reymont een grondig kenner van het dorpsleven. Zijn roman in vier deelen: 'De Boeren' schildert het bestaan van het Poolsche dorp zoals dit voor den wereldoor$\log$ was, met meesterlijke kunst.

In 1926 verscheen het uitgebreide artikel Ladislaw Reymont van Henri Ch.C.J. van der Mandere in het tijdschrift Den Gulden Winckel. In de jaren zestig van de twintigste eeuw zijn er ook publicaties verschenen waarin het werk van Reymont werd onderzocht. Zo werd in 1960 werd de monografie Wladislaw Stanislaw Reymont van de Belgische slavist C. Backvis gepubliceerd.

In de context van de regionale literatuur, maar ook in het kader van theoretische reflecties over de opbouw van Reymonts roman schrijft ook H.J.M.F. Lodewick (1975: 140). De auteur van het boek vergelijkt de structuur van De vlaschaard met de structuur van De boeren. Hij heeft vastgesteld dat in Streuvels' romans de namen van de hoofdstukken (De zaaihede, De wiedsters, Bloei, De slijting) niet naar de kalender verwijzen, maar naar de tijd die door de natuur wordt bepaald vanwege veldwerken. Reymont verdeelde zijn roman in vier seizoenen: Herfst, Winter, Lente, Zomer. Zowel de ene als de andere schrijver wijst erop dat de primaire kalender voor een boer de natuurlijke kalender is. Men zou kunnen zeggen dat het boerenleven volledig ondergeschikt is aan de natuur. 
Zes jaar later werd de bijdrage Witte Adelaar en Gouden Leeuw. Culturele en economische betrekkingen tussen Nederland en Polen door de eeuwen heen door Peter Krug (1981) geschreven die in Ons Erfdeel verscheen. In deze bijdrage presenteert de auteur onder andere de ontwikkeling van de Poolse letterkunde, waarbij hij aandacht vraagt voor een aantal belangrijke Poolse auteurs die ook in het Nederlands zijn vertaald. Krug noemt o.a. Henryk Sienkiewicz, Andrzej Strug, Witold Gombrowicz, Jarosław Iwaszkiewicz, M. Hłasko, Sławomir Mrożek, Stanisław Lem). Hij schreef over Reymont: "Een andere klassieke auteur, Wladyslaw Reymont (1867-1925), kreeg in 1924 de Nobelprijs voor literatuur voor zijn vierdelige werk De boeren" (Krug 1981: 506).

Op het einde van deze receptie is het nuttig om een Nederlandstalige licentiaatsverhandeling te vermelden die in 1999 jaar aan de Universiteit van Gent werd geschreven door Karen Horváth onder de titel Een vergelijkende studie tussen De vlaschaard (1907) van Stijn Streuvels en Chtopi (1902-1909) van Władystaw Stanisław Reymont. De auteur vergelijkt daar beide romans vanuit het perspectief van het naturalisme.

\section{Conclusie}

In de hier besproken romans die tot verschillende culturele gebieden behoren, kan men een gemeenschappelijke thematische noemer vinden: het beeld van het plattelandsleven. Verder hebben de romans van Streuvels en Reymont gemeenschappelijke kenmerken als de heimwee naar voorbije tijden, het hopeloze verlangen om terug te keren naar het dorp, nostalgie naar de natuur. De constructie van de personages blijkt ook gelijkvormig te zijn. De figuren zijn simpel, bijna primitief. De grond is de hoogste waarde voor hen. Hun leven draait rond de seizoenen. De vertellerconstructie is in beide boeken gelijkvormig, een alwetende verteller die in de derde persoon zijn verhaal vertelt. Deze elementen kunnen de universaliteit van streekromans bewijzen en bevestigen dat de boer met de grond verbonden is ongeacht de nationale grenzen.

Zoals aan het begin van deze bijdrage vermeld, heeft deze vergelijking een beknopt karakter. Niettemin kan dit thema in verdere discussie worden geanalyseerd in het bredere kader van de comparatistiek. Interdisciplinaire connotaties ondersteunen de taal van de literaire interpretatie. In dit geval is het uiterst belangrijk om de historische-geoculturele-culturele context verder te onderzoeken. 


\section{Bibliografie}

\section{Primaire literatuur}

Reymont, Władysław (2000): Chłopi. Gdańsk: Uniwersytet Gdański. Virtuele uitgave op http://literat.ug.edu.pl/chlopi/index.htm, op basis van de uitgave (ed.) H. Markiewicz \& J. Skórnicki, Władysław Stanisław Reymont. Dzieła wybrane. Kraków: Wydawnictwo Literackie 1957.

Streuvels, Stijn (z.j. = 1907): De vlaschaard. Amsterdam: L.J. Veen.

\section{Secundaire literatuur}

Adamowski, Jan (1995): "Sakralizacja przestrzeni w polskiej kulturze ludowej”. In: Bartmiński, Jerzy \& Jasińska-Wojtkowska, Maria (ed.): Folklor - sacrum - religia. Lublin: KUL, 20-31.

Backvis, Claude (1960): Wladislaw Stanislaw Reymont. Hasselt: Toorts 1960.

Bemong, Nele (2000): "Streekliteratuur in literatuurgeschiedenissen". In: Geest, Dirk de, Vanheste, Bert \& Sintobin,Tom (ed.): Van prototype tot karikatuur. Streekliteratuur in Nederland en Vlaanderen. Leuven: KU Leuven / Nijmegen: KU Nijmegen, 18-29.

Bork, G.J. e.a. (2012): Algemeen letterkundig lexicon. Laatst geraadpleegd op 21.11.2016 (http:// www.dbnl.org/tekst/dela012alge01_01/).

Brzóstowicz, Monika (1998): Wizerunek rodziny w polskiej prozie współczesnej. Poznań: Wydawnictwo PSP.

Debbaut, Romain (1989): Het naturalisme in de Nederlandse letteren. Leuven: Acco.

De Geest, Dirk e.a. (2005): "Streekliteratuur in Vlaanderen en Nederland: een probleemstelling”. In: Spiegel der Letteren 47, 2: 89-98.

Demedts, André (1982): "Streekliteratuur". In: Vlaanderen 31: 344-347.

Gazda, Grzegorz \& Tynecka-Makowiecka, Słowina (ed.) (2006): Słownik rodzajów i gatunków literackich. Kraków: Universitas.

Dietsche, Warande \& Belfort (1924): Jaargang 24. N.V. Het Vlaamsche Land, Antwerpen.

Feitsma, Anthonia (1976): Literatuur in sociaal perspectief. Amsterdam: Amsterdam University Press.

Dijk van, Diana \& Vaartjes Gé (1993): “Over Stijn Struevels”. In: Literatuur. Jaargang 10: 10.

Genette (1972): Gérard Figures III, Editions du Seuill.

Gloger, Zygmunt (1901): "Procesja krzyżowa". In: Gloger, Zygmunt: Encyklopedia staropolska ilustrowana, Vol. 2. Warszawa: P. Laskauer i W. Babicki, 210.

Horváth, Karen (1999): Een vergelijkende studie tussen De vlaschaard (1907) van Stijn Streuvels en Chtopi (1902-1909) van Wtadystaw Stanistaw Reymont. Gent, laatst geraadpleegd op 20.11.2016 (http://lib.ugent.be/catalog/rug01:000655319).

Ihnatowicz, Ewa (1997): “Kiedy kamienica jest a kiedy nie jest domem polskim”. In: Dąbek-Wigorowa, Teresa \& Makowiecki, Andrzej Z. (ed.): Obraz domu w kulturach stowiańskich. Warszawa: Uniwersytet Warszawski, 89-97.

Janssen, Emiel (1946): Stijn Streuvels en zijn vlaschaard: essay over zijn eerste productie tot aan het meesterwerk (1894-1907). Tielt: Lannoo.

Janssens, Marcel (1972): “Inleiding”. In: Stijn Streuvels, Verzamelde werken deel II. Brugge: Uitgeverij C. De Vries-Brouwers.

Janssens, Marcel (1992): "De vlaschaard. Stijn Streuvels". In: Meijde, A.G.H. Anbeek van der \& Janssens, Marcel (ed.): Lexicon van literaire werken. Groningen: Wolters-Noordhoff, 1-10.

Janssens, Marcel (2007): "Boer tegen de luchten en vader tegen de zoon". In: De Smedt, Marcel (ed.): Wie heet er u te slijten? Over De vlaschaard van Stijn Streuvels. Jaarboek 12 van het Stijn Streuvelsgenootschap 2006. Tielt: Lannoo, 109-113. 
Kocówna, Barbara (1975): Reymont. Z dziejów recepcji twórczości. Warszawa: PWN.

Krug, Peter (1981): "Witte Adelaar en Gouden Leeuw. Culturele en economische betrekkingen tussen Nederland en Polen door de eeuwen heen". In: Ons Erfdeel 24: 493-507.

Kulawik, Adam (1997): Poetyka. Kraków: Antykwa.

Lodewick, H. (1975): Literaire kunst. Den Bosch: Malmberg.

Mandere, Henri Ch.C.J. van der (1926): "Ladislaw Reymont”. In: Den Gulden Winckel 25: 123-125.

Marat, S. (1975): "W Reymontowskich Lipcach". In: Dziennik Ludowy 157.

Miner, Earl Roy (1990): Comparative poetics. An Intercultural Essay on Theories of Literature. Princeton (NJ): Princeton University Press.

Niewiadomski, Donat (1995): "Sacrum chrześcijańskie w inicjalnych rytach orki i siewu". In: Bartmiński, Jerzy \& Jasińska-Wojtkowska, Maria (ed.): Folklor - sacrum - religia. Lublin: KUL, 82-91.

N.N. (1924): "Wladyslaw Reymont". In: "Varia”. De Dietsche Warande en Belfort 24: 949-950.

Packard, Richard (1990): Refractions. Writers and Places. New York: Carroll \& Graf Publishers.

Pageaux, Daniel-Henri (1994): La littérature générale et comparée. Paris: A. Colin.

Rurawski, Józef (1988): Władysław Reymont. Warszawa: Wiedza Powszechna.

Rybicka, Elżbieta (2012): “Od poetyki do polityki miejsca. Zwrot topograficzny w badaniach literackich”. In: Nycz, Ryszard \& Walas, Teresa (ed.): Kulturowa teoria literatury. Poetyki, problematyki, interpretacje, Vol. 2. Kraków: Universitas, 311-344.

Schoell, Frank L. (1925): Les Paysans de Ladislas Reymont. Paris: Société d'Edition les BellesLettres.

Sintobin, Ton (2002): Wie schaft er op de woorden? Vijf keer Streuvels lezen. Gent: KANTL.

Skoczek, Anna (ed.) (2005): Historia literatury polskiej. Młoda Polska, Vol. 7, 2 delen. Kraków: SMS.

Sławiński, Jerzy (2002): Słownik terminów literackich. Wrocław/Warszawa/Kraków: Open.

Speliers, Hedwig (1994): Dag Streuvels. Ik ken den wegen allen. Antwerpen: Kritak/Manteau.

Świrko, Stanisław (1961): "Przysłowia w „Chłopach” Reymonta”. In: Literatura Ludowa 5, 1-2: $27-32$.

Wiesiołowski, Aleksander N. (1966): "Poetyka historyczna”. In: Skwarczyńska, Stefania (ed.): Teoria badań literackich za granica, Vol. 1, deel 2. Kraków: Wydawnictwo Literackie, 328-353.

Wyka, Kazimierz (1968): "Próba nowego odczytania Chłopów Reymonta". In: Pamiętnik Literacki 59, 2: 57-105.

Joanna Wlodarczyk $(* 1980)$ is sinds 2007 verbonden aan de Johannes Paulus II Katholieke Universiteit te Lublin. Zij is geïnteresseerd in de receptie van Poolse werken in Nederland en de receptie van Nederlandse literatuur in Polen. Haar dissertatie, verdedigd in 2013, ging over een vergelijking van Poolse en Vlaamse streekliteratuur.

e-mail: joannawlodarczyk@kul.lublin.pl 